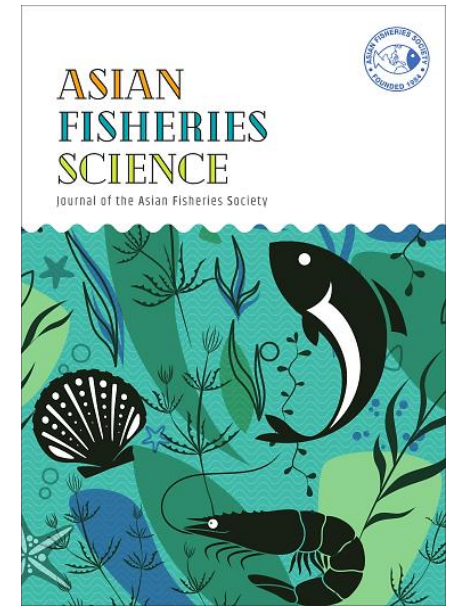

(c)Asian Fisheries Society

ISSN: 0116-6514

E-ISSN: 2073-3720

https://doi.org/10.33997/j.afs.2020.33.4.008
SHORT COMMUNICATION

\section{First Report of Xanthic Phenotype of the Common Bream Abramis brama (Linnaeus, 1758) from Krasnoyarsk Reservoir, Russian Federation}

\section{NIKITA O. YABLOKOV*, ALEXEY V. KLUNDUK, YULIA YU. FORINA}

Krasnoyarsk Branch of Russian Federal Research Institute of Fisheries and Oceanography (FSBSI, VNIRO), Parizhskoy kommuny st., 33 Krasnoyarsk 660049, Russian Federation

*E-mail: noyablokov@mail.ru |Received: 20/10/2020; Accepted: 27/11/2020

\begin{abstract}
Abnormal body colouration in fishes usually occurs as either a deficiency or an excess of various pigmented substances. Despite the fact that abnormal pigmentation is known in many fish species, they are extremely rare and of significant interest from the point of view of aquaculture, evolutionary biology and behavioural ecology. One of the forms of abnormal pigmentation is xanthism, expressed by the appearance of a yellow or orange colour. The article reports about the capture of a female common bream Abramis brama (Linnaeus, 1758) with abnormal xanthic colouration in the Znamensky Bay of the Krasnoyarsk Reservoir, Russian Federation ( $54^{\circ} 26^{\prime} 07.2^{\prime \prime} \mathrm{N}, 91^{\circ} 11^{\prime} 55.3^{\prime \prime} \mathrm{E}$ ) in June 2020. The xanthic individual had a pinkish-orange colouration of the dorsal and sides of the body, and the pectoral fins. The pelvic, dorsal, caudal, and anal fins are dark orange in colour and almost brown at the tips. The aetiology of abnormal pigmentation as in this case is not always clear. It is assumed that this variation of the common bream pigmentation is caused by a non-pathological genetic mutation, as in the cases of many other fish species described in scientific literature currently.
\end{abstract}

Keywords: xanthism, abnormal pigmentation, common bream

\section{Introduction}

The body colouration of fish is due to the presence and combination of black (melanophores), red and yellow pigment cells (xanthophores and erythrophores) (Burton, 2002; Yarzhombek and Zhukova, 2018). The distribution, density and size of each of the cell types mentioned above determine the colour range and intensity of pigmentation of the fish integument (Burton, 2002). Irregularities in the pigment systems lead to the appearance of aberrant forms of colouration. Among the main types of aberrations are usually albinism (lack or absence of certain pigments), melanism (excess of pigments, usually melanin), and ambicolouration (differences in the pigmentation of some parts of the fish body, normally coloured uniformly) (Moore et al., 1974; Muto et al., 2013). The appearance of such phenotypic deviations in the colouration of fish and other living organisms is of considerable interest in evolutionary biology (Nelson and Planes, 1993; Baer et al., 1995).
One of the most notable forms of colour aberrations is the appearance of orange or yellow body colour in some fish, so-called xanthism, or golden colouration (Dawson and Heal, 1976; Valencia-Méndez et al., 2018). Individuals with aberrant xanthic colouration have now been recorded for many species of orders Perciformes (Denoncourt et al., 1976), Gadiformes (Quigley et al., 2017), Salmoniformes (Dawson, 1964), Cypriniformes (Kobayasi, 1957; Vekhov, 2008), Cyprinodontiformes (Turner and Liu, 1977) and others (Dawson, 1964; Dawson and Heal, 1976). Xanthism is most widespread in Cypriniformes (Kobayasi, 1957; Vekhov, 2008; Podushka, 2013; Pawar and Jawad, 2017). Such deviations in pigmentation became the basis for the breeding of decorative forms of crucian carp (goldfish) Carassius auratus (Linnaeus, 1758), common carp (koi) Cyprinus carpio Linnaeus, 1758 (Yarzhombek and Zhukova, 2018), ide (orfe) Leuciscus idus var. orfus (Linnaeus, 1758) (Koopmans and van Emmerik, 2004), tench Tinca tinca (Linnaeus, 1758) (Kvasnicka et al., 1998). In natural populations, there are also known 
cases of catching golden individuals of roach Rutilus rutilus (Linnaeus, 1758) (Podushka, 2013), silver carp Hypophthalmichthys molitrix (Valenciennes, 1844) (Pawar and Jawad, 2017), mud loach Misgurnus anguillicaudatus (Cantor, 1842)(Kobayasi, 1957).

According to currently existing scientific publications, the presence of a xanthic phenotype in common bream has not previously been recorded in either wild or artificial habitats. The aim of this study was to describe for the first time the presence of a xanthic phenotype in this fish species.

\section{Materials and Methods}

During the annual monitoring studies on 4 June 2020 in the Znamensky Bay of the Krasnoyarsk Reservoir, Russian Federation (54²6'07.2"N, 9111'55.3"E) an individual of the common bream Abramis brama (Linnaeus, 1758) with a xanthic colouration was captured. An aberrant bream was caught with a gill net with a mesh size of $50 \mathrm{~mm}$, set at a distance of about $100 \mathrm{~m}$ from the coast at $5 \mathrm{~m}$ depth. The specimen was photographed, and then the total (TL), standard length (SL) and weight (W) were measured. Scales were used to determine the age.

Later, during the monitoring studies in the reservoir from June to July 2020, 1418 specimens of common bream were examined for xanthic colour, but were not found.

\section{Results}

The captured individual of common bream was a female, and had the following dimensional characteristics: $T L=297 \mathrm{~mm}, \mathrm{SL}=231 \mathrm{~mm}, \mathrm{~W}=242 \mathrm{~g}$. The age of xanthic individual was $4+$ years. The specimen was identified as common bream based on the following morphological characteristics: the number of scales in the lateral line 56 ; the number of rays in the dorsal fin 12 ; the number of rays in anal fin 27; specific sub-interior mouth, which can be extended as tube (Kotellat and Freyhof, 2007). It should also be noted that the ichthyofauna of the Krasnoyarsk Reservoir does not include species belonging to the genera Ballerus, Blicca, and Vimba, which can be confused with A. brama (Popov, 2015). These facts allow us to consider the described individual as a common bream.

Common bream is an introduced species in the Yenisei river system. Stocking of bream in the Krasnoyarsk Reservoir was carried out at the initial stages of reservoir formation in the period from 1964 to 1970. Subsequently, bream spread throughout the water area of the reservoir and currently is it one of the most abundant commercial fish species here (Zuev et al., 2016).

Normally, the body colour of common bream varies from silvery with a bluish tint in young individuals to dark gray with a yellow tint in large fish. The dorsal and top of the head are blackish-gray, the belly is almost white. The pectoral fins are dark gray or brownish, the other fins are darker, with almost black edges (Kottelat and Freyhof, 2007). The discovered individual had a pinkish-orange colouration of the dorsal and sides of the body. The belly is lighter than the sides of the body with a silvery sheen. The pectoral fins are pinkish-orange; the pelvic, dorsal, caudal, and anal fins are darker in colour and almost brown at the tips (Fig. 1).

\section{Discussion}

It is known that the orange or yellow colour of the integument of the body of fish is due to the content of carotenoid pigments or pterins in xanthophore cells (Yarzhombek and Zhukova, 2018). At the same time, pterin pigments are synthesized directly in the fish organism, and carotenoids are supplied exclusively with food. Some researchers note that pterin pigments mainly determine the colour of cyprinids (Matsumoto et al., 1960; Yarzhombek and Zhukova, 2018). Changes in the density of orange pigment cells may significantly alter the body colour of the fish (Webber et al., 1973). Angus and Blanchard (1991) have

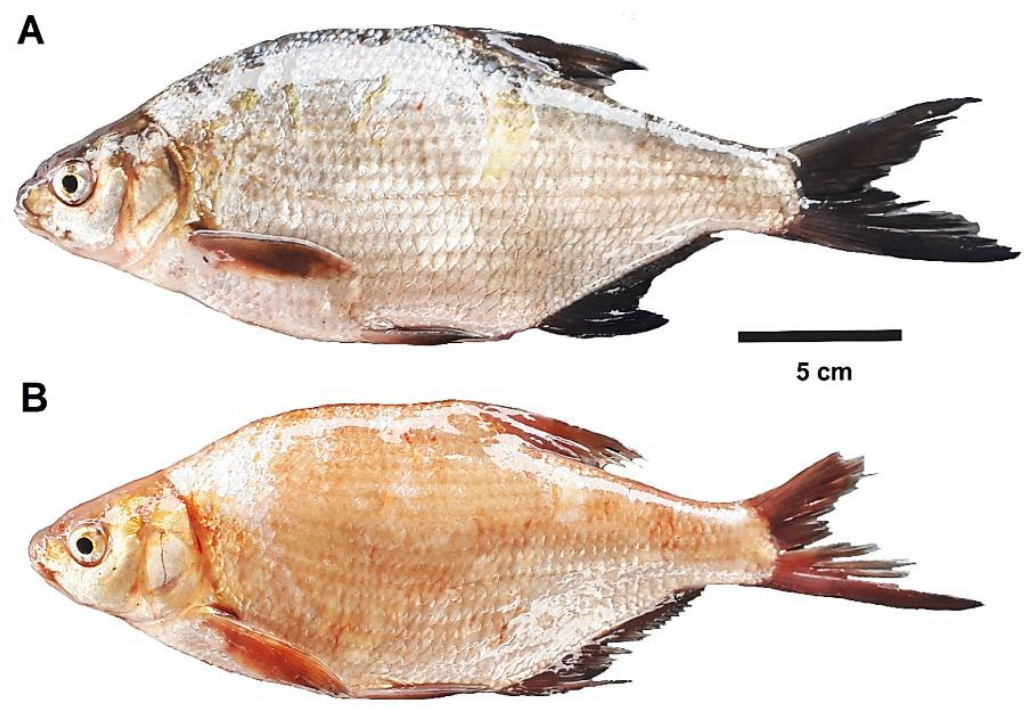

A

B
Fig. 1. Individuals of common bream with normal (A) and xanthic (B) colouration, Znamensky Bay, Krasnoyarsk Reservoir, Russian Federation, June 2020. 
suggested that xanthophores can be overproduced in the absence of melanophores or other pigment cells. The complete or partial disappearance of melanophores, in turn, leads to the appearance of orange or yellow (xanthic) colouration in some individuals (Webber et al., 1973).

In most fish species, xanthism is a rare variant of pigmentation (Palacios-Salgado and Rojas-Herrera, 2012). The case of xanthic pigmentation in A. brama described in this study demonstrates almost complete absence of dark pigment in body colouration. The closest colour variants among cyprinids were previously observed in the common roach in a number of water bodies of the European part of Russia and in the Rutilus heckelii (Nordmann, 1840) (Podushka, 2013). Other species of this family in natural populations, characterized by the presence of individuals with an aberrant xanthic colouration, in most cases, have a more intense orange colour and the cornea of the eye, bearing clusters of dark pigment spots (Kobayasi, 1957; Kvasnicka et al., 1998; Koopmans and van Emmerik, 2004; Yarzhombek and Zhukova, 2018). In the common bream individual that we described, dark pigment was present exclusively along the edges of the anal and caudal fins; however, the colour intensity was significantly lower than in the normally coloured individuals. According to a number of researchers, variations in xanthic colouration, in which an individual has no or practically no normally coloured body parts, are caused by a recessive mutation of the xanthophore genes (Lister et al., 1999; Watanabe and Kondo, 2015; Pawar and Jawad, 2017.). The xanthic pigmentation observed in A. brama from the Krasnoyarsk Reservoir is probably one of the variants of such mutation. Mechanisms of occurrence and inheritance of this colouration require further study.

\section{Conclusion}

The individual of common bream Abramis brama (Linnaeus, 1758) with a xanthic colouration caught in the Krasnoyarsk Reservoir is the first case of such aberration in this fish species described in the scientific literature. In the future, the study of the mechanisms of the emergence and inheritance of such colour variants in bream can serve as a basis for breeding decorative forms of this species, by analogy with trout, rudd, carp, ide, or other species. In addition, field and experimental studies of aberrantly coloured fish will make it possible to form ideas about intraspecific (including relationships in a school, reproductive success) and interspecific aspects of behaviour (predator-prey relationships).

\section{References}

Angus, R.A., Blanchard, P.D. 1991. Genetic basis of the gold phenotype in sailfin mollies. Journal of Heredity 82:425-428. https://doi.org $\underline{\text { /10.1093/oxfordjournals.jhered.a111118 }}$
Baer, C.F., Dantzker, M., Ryan, M.J. 1995. A test for preference of association in a colour polymorphic poeciliid fish: laboratory study. Environmental Biology of Fishes 43:207-212. https://doi.org /10.1007/BF00002493

Burton, D. 2002. The physiology of flatfish chromatophores. Microscopy Research and Technique 58:481-487. https://doi.org /10.1002/jemt.10166

Dawson, C.E. 1964. A bibliography of anomalies of fishes. Gulf and Caribbean Research 1:308-399. https://doi.org/10.18785/grr.0106.01

Dawson, C.E., Heal, E. 1976. A bibliography of anomalies of fishes: Supplement 3. Gulf and Caribbean Research 5:35-41. https://doi.org /10.18785/grr.0502.05

Denoncourt, R.F., Robbins, T.W., Stauffer, J. R. 1976. A description of xanthic tessellated darters, Etheostoma olmstedi (Teleostei: Percidae). Copeia 4:813-815. https://doi.org/10.2307/1443472

Kobayasi, H. 1957. On the colour variations of the mud loach, Misgurnus anguillicaudatus (Cantor). Journal of the Faculty of Science, Hokkaido University. Series 6, Zoology 13:63-66.

Koopmans, J.H., van Emmerik, W.A.M. 2006. Kennisdocument winde, Leuciscus idus (Linnaeus, 1758). Sportvisserij Nederland, Bilthoven. 50 pp.

Kottelat, M. Freyhof, J. 2007. Handbook of European freshwater fishes. Kottelat, Cornol \& Freyhof, Berlin. 646 pp.

Kvasnicka, P., Flajshans, M., Rab, P., Linhart, O. 1998. Inheritance studies of blue and golden varieties of tench (Pisces: Tinca tinca L.). Journal of Heredity 89:553-556. https://doi.org/10.1093/jhered $\underline{189.6 .553}$

Lister, J.A., Robertson, C.P., Lepage, T., Johnson, S.L., Raible, D.W. 1999. Nacre encodes a zebrafish microphthalmia-related protein that regulates neural-crest-derived pigment cell fate. Development 126:3757-3767.

Matsumoto, J., Kajishima, T., Hama, T. 1960. Relation between the pigmentation and pterin derivatives of chromatophores during development in the normal black and transparent scaled types of goldfish (Carassius auratus). Genetics 45:1177-1189.

Moore, C.J., Posey, Sr.C.R. 1974. Pigmentation and morphological abnormalities in the hogchoker, Trinectes maculatus (Pisces, Soleidae). Copeia 3:660-670. https://doi.org/10.2307/1442679

Muto, N., Noda, T., Kai, Y., Nakabo, T. 2013. First record of albinism in the rockfish Sebastes pachycephalus complex (Scorpaeniformes: Scorpaenidae). Ichthyological Research 60:195-197. https://doi.org /10.1007/s10228-012-0320-0

Nelson, C.M., Planes, K. 1993. Female choice of nonmelanistic males in laboratory populations of the mosquitofish, Gambusia holbrooki. Copeia 4:1143-1148. https://doi.org/10.2307/1447097

Pawar, R.T., Jawad, L.A. 2017. First report of a xanthic phenotype of the silver carp, Hypophthalmichthys molitrix (Valenciennes, 1844) (Teleostei: Cyprinidae) from Maharashtra Fish Seed Production Centre, India. International Journal of Aquaculture 3:101-105. http://dx.doi.org/10.5376/ija.2017.07.0015

Podushka, S.B. Tsvetovye aberratsii u plotvy (Colour aberrations of the roach). 2013 http://sevrjuga.narod.ru/Literatura/Statjia168.doc (Accessed 25 August 2020)(in Russian).

Popov, P.A. 2015. Distribution of cyprinid fish in the reservoirs of the Siberian subarctic region. Contemporary Problems of Ecology 8:6571. https://doi.org/10.1134/S1995425515010102

Quigley, D.T.G., Lord, R., MacGabhann, D., Flannery, K. 2017. First records of xanthochromism in three-bearded rockling Gaidropsarus vulgaris (Cloquet 1824) and pollack Pollachius pollachius (Linnaeus 1758). Journal of Applied Ichthyology 33:1208-1210. https://doi.org /10.1111/jai.13456 
Turner, B.J., Liu, R.K. 1977. Xanthic variants in a natural population of the Salt Creek Pupfish, Cyprinodon salinus. The Southwestern Naturalist 22:538-540. https://doi.org/10.2307/3670156

Valencia-Méndez, 0., Domínguez-Domínguez, 0., López-Pérez, A. Martínez-Gómez, J.E., Ayala-Bocos, A. 2018. Partial albinism in the Revillagigedo sea chub Kyphosus sectatrix (Perciformes: Kyphosidae) from Clarion Island, Mexico. Revista Mexicana de Biodiversidad 89:572-576. https://doi.org/10.22201/ib.20078706e .2018 .2 .2242

Vekhov, D.A. 2008. Population of silver crucian carp Carassius auratus (Cypriniformes, Cyprinidae) with «golden» individuals in the pond of the city of Volgograd. Journal of Ichthyology 48:326-335. https://doi.org/10.1134/S003294520804005X

Watanabe, M., Kondo S. 2015. Is pigment patterning in fish skin determined by the Turing mechanism? Trends in Genetics 31:88-96. https://doi.org/10.1016/j.tig.2014.11.005

Webber, R., Barlow, G.W., Brush, A.H. 1973. Pigments of a color polymorphism in a cichlid fish. Comparative Biochemistry and Physiology Part B: Comparative Biochemistry 44:1127-1135. https://doi.org/10.1016/0305-0491(73)90265-4

Yarzhombek, A.A, Zhukova, K.A. 2018. Red and orange skin colour of fish. Trudy VNIRO 170:124-129.

Zuev, I.V., Vyshegorodtsev, A.A., Chuprov, S.M., Zlotnik, D.V. 2016. Modern composition and distribution of alien fish species in the water bodies of the Krasnoyarsk Territory. Russian Journal of Biological Invasions 7:324-332. https://doi.org/10.1134 $\underline{\text { IS2075111716040123 }}$ 